\title{
Exploring the roles of students' home resources and attitudes towards science in science achievement: a comparison of South Korea, Turkey, and the United States in TIMSS 2015
}

\author{
Rachel Louise Geesa ${ }^{1 *}$ D, Burcu Izci ${ }^{2}$, Hyuksoon S. Song ${ }^{3}$ and Shiyi Chen ${ }^{4}$
}

\footnotetext{
* Correspondence: rlgeesa@bsu.edu ${ }^{1}$ Department of Educational Leadership, Teachers College (TC), Ball State University, Room 903, Muncie, IN 47306-0590, USA Full list of author information is available at the end of the article
}

\begin{abstract}
Educational opportunities in the home, at school, and within the community differ across countries and affect students' achievement and future success in science fields. Bandura's Social (Social foundations of thought and action: A social cognitive theory, 1986) and Bronfenbrenner's Ecological System Theory (Ecological models of human development. In International Encyclopedia of Education, 1994) both support the notion that students' attitudes towards science and home resources can be associated with their academic achievement. In order to examine the possible home and student level factors in science achievement, we examined fourth graders' home resources and attitudes towards science in the Trends in International Mathematics and Science Study (TIMSS) 2015 in South Korea, Turkey, and the United States where students' science achievement scores varied. Findings from multiple linear regression analyses indicated that having a positive attitude toward science and more home resources positively related to fourth grade students' science scores. Among different home resources, the number of books owned at home appeared to better predict students' science scores. Providing students with science books in early grades may increase their interest in science and contribute to their science achievement in the future. Longitudinal studies of science achievement in these three countries and other countries may be included in further research.
\end{abstract}

Keywords: Elementary/primary school, Attitudes, Home resources, Learning environment, Science education, TIMSS 
(Continued from previous page)

터키, 그리고 미국의 초등학교 4 학년 학생들의 가정에서의 학습 자원과 과학에 대한 태도에 관한 내용을 분석하였다. 다중회귀분석을 통해 학생들이 과학에 대해 긍정적인 태도를 가질수록, 그리고 가정에 학습 자원이 풍부할수록, 그들 의 과학 학업 성취에 긍정적인 영향을 끼쳤음을 알 수 있었다. 그리고 가정의 학습 자원 중, 집에서 소유하고 있는 책의 숫자가 학생들의 과학 성적을 가장 잘 예측하는 요인임을 알 수 있었다. 즉, 어린 시절에 학생들에게 과학에 관한 책을 많이 제공하는 것이 과학에 대한 흥미를 가지게 할 수 있으며, 차후 과학 학업 성취에도 영향을 끼치게 된다. 계속해서 이 세 나라의 과학 학업 성취에 관한 종단적 연구가 필요하다고 본다.

\section{Özet}

Ev ortamında, okulda ve toplumda yer alan eğitim fırsatları her ülkede değişkenlik göstermekte olup, öğrencilerin fen bilgisi alanındaki başarılarını etkilemektedir. Bandura'nın Sosyal-Bilişsel Öğrenme Kuramı ve Bronfenbrenner'in Ekolojik Sistemler Kuramı, öğrencilerin fen bilimlerine olan tutumları ve evlerinde yer alan eğitici kaynakların akademik başarı ile ilişkisini desteklemektedir. Ev ortamı ve öğrenci ile ilişkili değişkenlerin fen başarısına olan etkisini araştırmak için, 4. sınıf öğrencilerinin evlerindeki eğitici kaynaklar ve fen bilimlerine olan tutumları, Uluslararası Matematik ve Fen Eğilimleri Araştırması'nın (TIMSS 2015) sonuçları kullanılarak incelenmiştir. Uluslararası Matematik ve Fen Eğilimleri Araştırması'na göre (TIMSS 2015) Güney Kore, Türkiye ve Amerika Birleşik Devletleri'ndeki 4. sınıf öğrencilerinin fen başarıları değişkenlik göstermektedir. Çoklu regresyon analizi sonuçlarına göre 4. sınıf öğrencilerinin fen bilimlerine olan olumlu tutumları ve evdeki eğitici kaynakların sayısı fen başarıları ile ilişkilidir. Öğrencilerin evlerinde sahip oldukları kitap sayısı, evde bulunan diğer çeşitli eğitici kaynaklar ile kıyaslandığında, fen başarı puanlarını öngörmede en çok etki eden değişken olmuştur. Öğrencilere okulun ilk yıllarından itibaren fen bilimleri alanında kitaplar temin etmek, öğrencilerin gelecekteki fen bilimlerindeki başarılarına olumlu katkı sağlayabilir. Bu makalede yer alan üç ülke ve daha başka ülkeler de öğrencilerin fen başarılarını inceleyen uzun vadeli çalışmalara dahil edilebilir.

\section{Introduction}

Science, technology, engineering, and mathematics (STEM) have received widespread attention from educators, researchers, and policy makers in the last decade (e.g., Bybee 2010a, 2010b; Kuenzi 2008). Educational content in STEM disciplines includes students developing abilities to ask questions, collect data, test ideas, solve problems, and apply what they learn. Focusing on science education, it is believed that education related to science helps prepare citizens with 21st century skills (Bybee 2010a, 2010b; Cheung 2018), as well as support individual country's success in economic growth and contest in the global market (Engler 2012). Internationally, there is a focus on students' achievement in science (Carnoy and Rothstein 2013) and competition to gain professional and academic positions in science fields has rapidly grown (Fayer et al. 2017). Results from large scale international studies focused on STEM-based subjects (e.g., Trends in International Mathematics and Science Study [TIMSS], Programme from International Student Assessment [PISA]) provide stakeholders, such as educators, researchers, parents/guardians, and policymakers, insights regarding their students' 
achievement status based on individual and collective scores compared to scores of other countries.

\section{TIMSS and science education in elementary school}

Science education helps students use critical thinking skills, understand issues, and find proper solutions for problems (Halim and Mokhtar 2015). If students have high-quality science education in elementary school years, they are more likely to carry their enthusiasm about science over time (National Science Teaching Association (NSTA) 2018). When students find science subject matter interesting and engaging, their desire to continue studying and exploring science topics and activities may expand (Wellcome Trust 2011).

Given the importance of science in early grades to promote further achievement and interest in science in later grades (National Science Teaching Association (NSTA) 2018; Wellcome Trust 2011), governments and stakeholders make attempts to improve their education systems and science curriculum. One of their attempts includes participation in international science and mathematics achievement studies (TIMSS and PIRLS International Study Center 2014). For example, TIMSS is a large-scale international study that monitors fourth and eighth grade trends in students' science and mathematics education and attitudes towards the subjects at home and school throughout the world. Since 1995, TIMSS has been offered to countries to participate in every 4 years. Indeed, TIMSS data provide countries with information to develop and broaden international perspectives of the strengths, weaknesses, and areas of improvement in education disciplines and achievement (Martin et al., 2016a).

Forty-seven countries participated in the TIMSS 2015 science portion, and fourth grade science achievement scores vary between participating countries. Four of the top five achieving countries in fourth grade science in TIMSS 2015 were from East Asian countries including Singapore, South Korea, Japan, and Hong Kong SAR. East Asian countries' success in science has received attention from researchers in recent years, as several comparative studies examining science achievement between Eastern and Western countries have been conducted with eighth grade students (e.g., Chiu 2008; Shen and Tam 2008; Wilkins 2004; Yoshino 2012; Yu 2012). As opposed to prior research about eighth graders, a limited number of research conducted about fourth graders exist to understand possible factors affecting student achievement across countries (Kaya and Rice 2010).

Students' science achievement across countries could be related to various factors including students' home resources, cultural differences, and attitudes towards science (Topçu et al. 2016). Students' home resources were found to be associated with fourth graders' science achievement in TIMSS 2011 (Martin et al. 2012). Similarly, based on TIMSS 2015 data, students who had more home resources (e.g., books, private rooms, and internet connections) had higher achievement scores in science, compared to their peers who had some or few resources in their homes (Martin et al., 2016a). Mohammadpour et al. (2015) found an association between eight graders' confidence in science and their science achievement in TIMSS 2007. By employing a multilevel data analysis method, Mohammadpour et al. (2015) investigated factors at the student, school, and country level. They reported that students' confidence in science contributed 
significantly to their science achievement, controlling for covariates such as gender, SES, and school climate (Mohammadpour et al. 2015). In addition to student level factors, cultural differences and expectations may affect students' achievement in science (Mann and DiPrete 2016). Western cultures tend to focus on independence and individual thinking, while Eastern cultures focus more on interdependence and collective thinking (Long 2016; Schütte 2015). The differences between cultural expectations, which emphasize individualism, and cultures, which emphasize collectivism, may indicate variance in students' motivation to achieve higher in science (Long 2016; Schütte 2015).

Home resources are important indicators of students' family background and have been found to be associated with their science achievement (Kaya and Rice 2010); attitude towards science not only predict science scores but also reflect a larger culture and school climate related to science (Tsai and Yang 2015). Together, both home resources and attitudes are important elements that influence one's learning motivation and achievement according to the Social Cognitive Theory (Bandura 1986). Hence, home resources and attitudes towards science were chosen as the focal points of this study. To our knowledge, only a few studies compared fourth graders' science achievement in participating countries of TIMSS where students' achievement scores differed as a result of various home or student level factors. In order to shed light to this neglected area, we conducted this comparative study to identify fourth grade students' home resources and attitudes towards science as well as these factors' contributions to science achievement in three countries representing three achievement tiers (i.e., low, mid, and high) in TIMSS 2015. Specifically, some home resources we investigated were such as the number of books, having a private room, having Internet connections at home. Attitudes towards science referred to students' self-reported confidence in and outcome expectation of science.

The purpose of this study is to further explore the influence of these two factors using a more up-to-date TIMSS dataset and focusing on three diverse countries. Countries throughout the world have varying education programs, and we selected three countries with varied science achievement scores, unique cultural norms, and educational curricula, which would be understood and explained by the authors. According to TIMSS 2015 report (Martin et al., 2016a), fourth graders' science achievement is compared across three countries: South Korea ${ }^{1}$ (one of the top achievers), Turkey (below the international average), and the United States $^{2}$ (above the international average) (see Fig. 1).

\section{Theoretical framework}

Two theories were selected as the theoretical frameworks for this study. First, Bandura's Social Cognitive Theory suggests triadic reciprocity referring to the dynamic and reciprocal interaction of person, behavior, and environment (Bandura 1986). For example, the way of thinking influences behavior and behavior also affects the individual's thinking, attitudes, and beliefs. Moreover, Social Cognitive Theory emphasizes

\footnotetext{
${ }^{1}$ South Korea is listed as Korea or Republic of Korea in the Trends in International Mathematics and Science Study (TIMSS). For consistency purposes, South Korea is used to represent Korea or Republic of Korea throughout this paper.

${ }^{2}$ In the TIMSS, the United States represents the United States of America or the USA. For consistency purposes, the United States is used to represent the United States of America or the USA throughout this paper.
} 


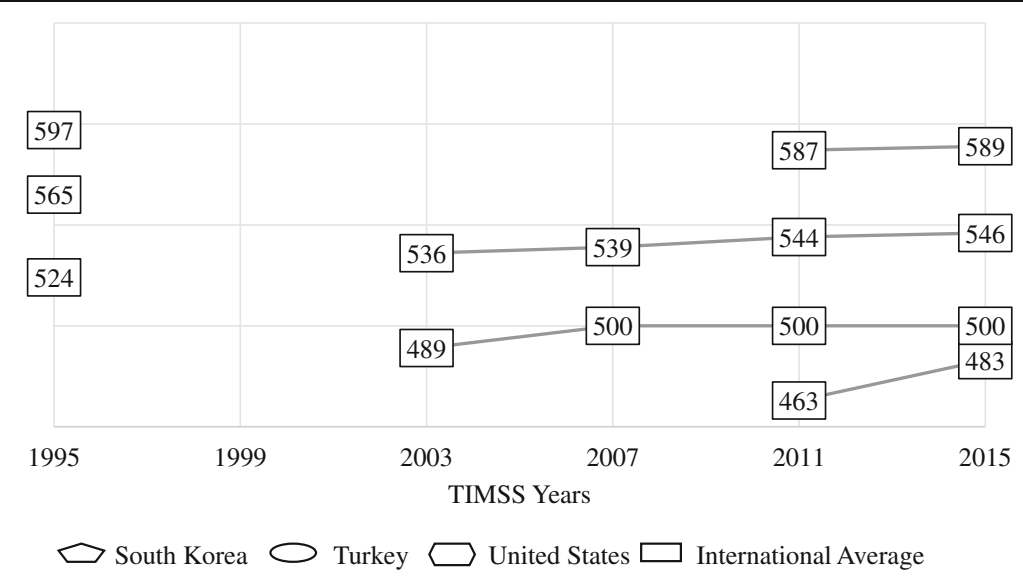

Fig. 1 Fourth Graders' Science Achievement in TIMSS in South Korea, Turkey, and the United States. Data indicate the average science achievement scores by country and year (Martin et al., 2012; Martin et al. 2016a). The TIMSS is administered once every four years since 1995. South Korea and Turkey did not participate each year that it was administered. The TIMSS science portion was not offered to fourth grade students in 1999. The international average is the average score of all participating countries' science achievement scores accepted by the TIMSS organizers

social influence and reinforcement (Stables et al. 2018). The environmental factors, such as social context, influence the individual's cognition, metacognition, and motivation (Zimmerman and Schunk 2003). Students' attitudes towards science may be influenced by the science-based opportunities and resources they have at home, school, or throughout the community. According to Social Cognitive Theory, "people are producers as well as products of environmental conditions" (Zimmerman and Schunk 2003, p.438). Second, Bronfenbrenner's Ecological Systems Theory indicated that students' home context (such as availability of resources) might play a role in their development and learning (Bronfenbrenner 1994). Typically, elementary school students spend a large portion of their time with their families during the weekdays and weekends (Beck 2017). For this reason, the availability and number of home resources such as books, computers, or other resources for their learning may function as a contributor to students' learning and achievement in science. For instance, researchers identified that home environment and resources play a significant role in students' academic intrinsic motivation (Gottfried et al. 1998; Richards 2015).

According to Social Cognitive Theory and Ecological Theory, the interplay between family context (i.e., represented by home resources in this study) and personal factors (i.e., characterized by attitudes toward science in this study) explains the multifaceted nature of human behaviors, learning, and development (Stables et al. 2018). Deriving from these two theories and previous research, students' attitudes towards science (personal factor) and home resources (students' most relevant environment) were chosen as variables of interests. In the following sections, we reviewed the possible influence of attitudes, home resources, and broader education and social environment on students' science achievement.

Home level and student level factors affecting science achievement

Students' achievement and interest in science may drive their future success in STEM fields (Cheung 2018). In order to understand students' confidence in science, TIMSS 
developers created an index based on students' responses to several statements (e.g., "I usually do well in science," "Science is harder for me than any other subject") (Martin et al., 2016a). Based on TIMSS 2003 data, Kaya and Rice (2010) found that students' confidence in science and their home resources predicted fourth graders' science achievement. On average, one point increase in students' confidence in science affected their achievement scores in TIMSS 2003 (e.g., a 20 point achievement score increase in Japan and a 22 point achievement score increase in the United States, etc.) when students' gender and home resources were controlled (Kaya and Rice 2010).

It is well established that students' socioeconomic status (SES) is highly correlated with their science achievement (Agirdag 2018; Gustafsson et al. 2018). Home resources, as an important indicator of SES, are also related to students' science scores (Chen et al. 2012). Drawing on lessons learned from research about science capital (i.e., individual's knowledge and exposure of science) and science achievement, it is plausible to assume that students who have more educational resources at home tend to have more exposure to science related materials. Therefore, students may be more knowledgeable and skilled in the science subject domains (Archer et al. 2015). For instance, Tsai and Yang (2015) indicated that students' home resources (e.g., books, desk) were significantly related to achievement in science, controlling for their attitudes towards science. When students had more resources at home, they were more likely to have higher scores in science than their peers with fewer home resources and less positive attitudes, when holding their attitudes towards science constant (Tsai and Yang 2015). Similarly, Kaya and Rice (2010) also found that having more resources at home yielded a higher science score in five participating countries in TIMSS 2003 (i.e., United States, Singapore, Japan, Australia, and Scotland). Additionally, in a more recent study using TIMSS 2011 data, Topçu et al. (2016) reported that having richer home resources warranted a better science score. Topçu et al. (2016) argued that home resources such as internet access, books, and a private room were also indicators of parents' investments in students' learning and could contribute to students' exposure and learning of science.

\section{Education program and science curriculum by country}

Emphasis on science education in each country varies throughout the world. Academic achievement in TIMSS differs among South Korea, Turkey, and the United States. As previously discussed, we chose these three countries for this study due to the variance in science achievement scores, distinctive cultural expectations, and national education focuses. Based on TIMSS 2015 data, South Korea is one of the top achievers, Turkey is below the international average, and the United States is above the international average. Summaries of education programs, science curricula, and STEM education initiatives in these three countries are described below.

\section{South Korea}

South Korea is consistently ranked amongst the top for global education (Martin et al., 2016a). According to TIMSS 2015 data, South Korean fourth grade students ranked third in mathematics achievement and second in science achievement amongst peers in other countries (Martin et al., 2016a). In South Korea, 3.3 million students are enrolled 
in 5855 elementary schools, and 2 million students are enrolled in 3144 middle schools (Korean Ministry of Education 2017). A national curriculum is applied to all students in elementary and middle school students (Sang et al. 2016).

The science curriculum in South Korea is designed for all students in third through ninth grade; however, the students take some form of science throughout their K-12 education. The 2015 science curriculum aims to: 1) help students understand fundamental science concepts through activities involving inquiry; 2) motivate students to develop an interest in and curiosity about natural phenomena and objects; and 3) facilitate student development of scientific thinking skills and creative problem-solving abilities (Korean Ministry of Education 2017). Through the curriculum, various inquirybased activities are designed to develop student abilities such as observing, experimenting, investigating, and discussing (Mullis et al. 2016).

In South Korea, fourth grade students participated in TIMSS three times: 1995, 2011, and 2015 (Martin et al. 2012, 2016a). Results of TIMSS indicate that South Korean fourth grades consistently rank highly among other countries. In 2011, South Korea had the top average score with 587 points and ranked first of 52 countries (Martin et al. 2012). The country's fourth grade average science score rose slightly to 589 points in 2015, but their rank among 47 countries decreased to second place as Singapore took first place with one point higher score than South Korea (Martin et al., 2016a).

Education fever may be a factor in students' high academic achievement in STEM subjects throughout the country (Kim et al. 1993; Lee 2003). Most students in South Korea attend one or more private cram schools (hagwons) after their elementary school day (Choi and Cho 2016; Kim and Park 2010). Cram schools provide students with additional education to prepare students for South Korea's competitive college entrance examination system (Lee 2006). In general, parents in South Korea believe if a child excels at studying in grade school, then he or she may be able to continue education at a prestigious university which may lead to a higher status in political, economic, and social circumstances (Kim and Bang 2016; Lee 2006).

Science and mathematics education programs in South Korea are focused on the memorization of knowledge and repeated problem-solving practices to prepare competitive tests (Park et al. 2016). It led to high performance on international science and mathematics assessments such as TIMSS and PISA but produced low motivation and negative values on the subjects (Lee and Park 2010). To address this issue, the South Korean government proposed a policy for the reconstruction of science and mathematics education in 2011 and has supported the spread of STEAM (Science, Technology, Engineering, Art, \& Math) education into K-12 classrooms by curriculum revisions, funding initiatives, and teacher education programs (Martin et al. 2016b). It is mandatory in elementary and secondary schools to include $20 \%$ of STEAM related content in the curriculum (Park et al. 2016).

\section{Turkey}

The Ministry of National Education provides all educational and training activities for students in Turkey. Students, ages five to 13 years old, obtain free and compulsory 
education in public elementary and middle schools (Özdemir et al. 2016). In the 20172018 school year, 5.1 million students enrolled in 24,967 elementary schools (The Ministry of National Education 2018). Turkish students in first and second grades take a specific course called "Life Sciences," before they begin taking science courses in the third grade. Third graders have both Life Sciences (3 hours weekly) and science courses (3 hours weekly), while fourth graders have only 1 three-hour science course each week (Ministry of National Education, General Directorate of Innovation and Educational Technologies (YEĞİTEK) 2017).

Elementary school teachers teach science courses in the third and fourth grades (Özdemir et al. 2016). The main objective of the science curriculum in elementary and middle schools is providing student centered lessons as well as developing students' competencies such as problem solving, reasoning, project-based learning, and cooperating with others. The science curriculum in the fourth grade includes five learning areas: Physical Processes, Matter and Change, Life and Living Beings, Earth and the Universe, and Science and Engineering Practices (The Ministry of National Education of Turkey 2017).

Turkey participated in TIMSS at the fourth grade twice, in 2011 and 2015 (Martin et al. 2012, 2016a). In 2011, Turkey ranked 36th among 52 countries in fourth grade science achievement with 463 points (Martin et al. 2012). Four years later, Turkish students' achievement scores increased 20 points, but they ranked 35th of 47 countries in 2015 (Martin et al., 2016a). The emerging focus on STEM and science education could explain the 20-point increase in students' achievement scores in Turkey and students' interest and motivation to learn science. The slight change in Turkish students' rank in TIMSS 2015 may be associated with other countries' increased concentration on STEM education and training students to be competent in STEM career fields in the future (Akgündüz et al. 2015). As a result, Turkish researchers, educators, and national policymakers began emphasizing STEM education throughout the country to increase learning outcomes and curriculum in STEM disciplines in last few years (Ministry of National Education, General Directorate of Innovation and Educational Technologies (YEĞİTEK) 2016, 2017, \&, 2018).

\section{United States}

In the United States, each of the 50 states governs their state's education program (Malley et al. 2016). From kindergarten through the twelfth grade, students experience free, public education. Due to the decentralized education system, students begin schools at different ages based on the state. The average age students begin kindergarten is five, but kindergarten is not compulsory in all states (Malley et al. 2016). Most students (35.6 million) attend public schools in prekindergarten through eighth grade, and 5.2 million students attend private elementary and secondary schools (National Center for Education Statistics 2017a).

Like other curricular subjects in the United States, science curriculum varies among each state. The Next Generation Science Standards (NGSS) for kindergarten through twelfth grade students began to influence science education curriculum in 2013, with dimensions in natural sciences, scientific and engineering practices, and crosscutting concepts (Mullis et al. 2016; Next Generation Science Standards 2013). Science 
curriculum topics in elementary school typically include Earth and Space Sciences, Life Sciences, and Physical Sciences (Mullis et al. 2016).

Fourth grade students in the United States participated in TIMSS each of the five periods that it was offered in the fourth grade in 1995, 2003, 2007, 2011, and 2015 (Martin et al. 2012, 2016a). In TIMSS 2011, the United States science average score was 544, and the country ranked 7th among 52 countries (Martin et al. 2012). Fourth grade student achievement rose two points to 546 in 2015; however, the country's rank decreased to 10th with 47 countries (Martin et al., 2016a).

In the United States, the College and Career Readiness (CCR) standards and Every Student Succeeds Act (ESSA) have become driving forces in emphasizing the national need for students' achievement in STEM disciplines (Council of Chief State School Officers 2018; ESSA 2015; Malin et al. 2017). Schools may be supported with STEMrelated resources and training through local, national, and federal funding sources. To prepare students for careers and higher education, the focus on STEM education begins in elementary schools in the United States and continues throughout the students' PK12 education.

In this study, we focused on three research questions to explore home resources and attitudes towards science and students' science achievement between South Korea, Turkey, and the United States. We investigated the following questions:

1. What are the differences in students' home resources and attitudes towards science in South Korea, Turkey, and the United States?

2. Which home resources do predict the science achievement of fourth grade students in South Korea, Turkey, and the United States?

3. To what extent do home resources and attitudes towards science factors contribute to students' science achievement in the fourth grade in South Korea, Turkey, and the United States?

\section{Methods}

\section{Data sources and sample}

We analyzed TIMSS 2015 data for South Korea, Turkey, and the United States in this study by employing a multiple regression approach. The participants for this study were 21,154 fourth-grade students who participated in TIMSS 2015 in South Korea, Turkey, and the United States. TIMSS 2015 science achievement data and student background questionnaire data in South Korea, Turkey, and the United States were a part of this study.

\section{Measures}

From the TIMSS 2015 International Database, we analyzed publicly available data for South Korea, Turkey, and the United States. Students' fourth grade TIMSS 2015 science achievement data were collected for the three countries. From the student background questionnaire, we identified nine items under "Home Resources" for the home resources measure. These items included: number of books, use of computers or tablets at home for homework, ownership of computers or tablets, sharing of computers/tablets, and having a desk, room, internet connection, mobile phone, and gaming system 
Table 1 Student attitudes towards science

\begin{tabular}{l}
\hline \multicolumn{1}{c}{ Agree a lot } \\
\hline I enjoy learning science. \\
I learn many interesting things in science. \\
I like science. \\
I look forward to learning science in school. \\
Science teaches me how things in the world work. \\
I like to do science experiments. \\
Science is one of my favorite subjects. \\
I usually do well in science. \\
I learn things quickly in science. \\
My teacher tells me I am good at science. \\
I wish I did not have to study science. \\
Science is boring. \\
Science is harder for me than for many of my classmates. \\
I am just not good at science. \\
Science is harder for me than any other subject. \\
Science makes me confused.
\end{tabular}

at home. We selected 16 items to measure students' attitudes and competencies toward science (see Table 1). Adapted from the TIMSS 2015 questionnaire of fourth grade students, these items measure students' attitudes towards learning science (e.g., How much do you agree with these statements about learning science?) and science in general (e.g., How much do you agree with these statements about science?). Considering our study focuses on the students' individual interests toward the science subject area in general. The items about students' attitudes towards science lessons in schools are excluded.

Negatively worded attitudes items were reverse coded. Five plausible values in science achievement were entered as outcome variables of science achievement. We created two composite variables of home resources and students' attitudes towards science, as we aggregated scores to understand their predictive power on fourth graders' science achievement in South Korea, Turkey, and the United States. The reliability of the measurement is reported in the next section. Higher scores in those two composite variables indicate a higher number of resources at home and a more positive attitude towards science. For this study, descriptive statistics and multiple regression analyses were conducted.

\section{Data analysis}

A chain of multiple linear regression analyses was conducted to explore the influences of attitudes towards science and home resources to students' science achievement. We examined relations between a set of independent variables and the outcome variables in this analysis method (Cohen et al. 2003). Through cleaning the data and aggregating scores in SPSS Statistics 20, two composite variables (home resources and attitudes towards science) were created. Home resources composite variable includes the number of books, use of computers or tablets at home for homework, ownership of computers 
or tablets, sharing of computers/tablets, and having a desk, room, internet connection, mobile phone, and gaming system at home. The attitude towards science composite score includes 16 items measuring students' attitudes and competencies toward science.

In order to measure the internal reliability of the home resources and attitudes towards science composite variables, Cronbach's alpha coefficients were calculated by SPSS Statistics software. The Cronbach's alpha coefficient on the attitudes towards science composite variable was .91 for 16 items, whereas Cronbach's alpha for the nine items of the home resources composite variable was .47 . Though the home resources composite variable demonstrated limited internal consistency, it is comparable to those that were reported in similar studies. For instance, Chen and colleagues (Chen et al. 2012) reported $\alpha=.61$ for their home resources variable, using the TIMSS 2003 data; Topçu et al. (2016) found the $\alpha$ level of their home resources composite variable to be .59, using data from TIMSS 2011. The International Association for the Evaluation of Educational Achievement (IEA) International Database (IDB) Analyzer (Version 3.1.17) was utilized to conduct linear regressions. This database analyzer examines IEA survey data to confirm the proper usage of the complex plausible value technology (IEA 2013; Neuschmidt 2007). Results were produced as on-screen, SPSS data, and Microsoft Excel output files. For data analysis, composite variables of "home resources" and "attitudes towards science" and five plausible variables of students' science achievement were included. Linear regression was computed by using pairwise deletion for missing variables in the dataset.

To answer Research Question 1, descriptive statistics of differences in students' home resources and attitudes towards science among South Korea, Turkey, and the United States were defined. We inspected the influence of attitudes towards science and home resources composite variables on fourth grade students' science achievement in the three countries for Research Question 2. Additionally, we conducted three linear regressions with predictors set as individual home resources variables to identify which home resources had greater impacts on fourth graders' science achievement in South Korea, Turkey, and the United States to answer Research Question 3.

\section{Results}

Fourth graders' science achievement scores in TIMSS 2015 varied between South Korea, Turkey, and the United States (Martin et al., 2016a) (see Table 2). Students in South Korea had higher achievement scores in science compared to their peers in Turkey and the United States. Descriptive statistics of home resources and attitudes

Table 2 TIMSS 2015 fourth grade science achievement scores for South Korea, Turkey, and the United States

\begin{tabular}{ll}
\hline Country & TIMSS 2015 \\
\hline South Korea $(N=4669)$ & 589 \\
Turkey $(N=6456)$ & 483 \\
United States $(N=10,029)$ & 546 \\
International Average & 500 \\
\hline
\end{tabular}

Data were collected from the TIMSS 2015 International Results in Science reports (Martin et al., 2016a). The international average is the average score of all participating countries science' achievement scores accepted by the TIMSS organizers. TIMSS 2015 participants (N) are indicated per country 
Table 3 Descriptive statistics of fourth graders' home resources in South Korea, Turkey, and the United States

\begin{tabular}{|c|c|c|c|c|c|c|}
\hline \multirow[t]{2}{*}{ Home Resources } & \multicolumn{2}{|c|}{$\begin{array}{l}\text { South Korea } \\
(N=4669)\end{array}$} & \multicolumn{2}{|c|}{$\begin{array}{l}\text { Turkey } \\
(N=6456)\end{array}$} & \multicolumn{2}{|c|}{$\begin{array}{l}\text { United States } \\
(N=10,029)\end{array}$} \\
\hline & $M$ & S.D. & $M$ & S.D. & $M$ & S.D. \\
\hline $\begin{array}{l}\text { Books } \\
\text { (1: NoneNery few; 2: One Shelf; 3:Bookcase; 4: Two Bookcases; } \\
\text { 5:Three/More Bookcases) }\end{array}$ & 4.09 & 1.06 & 2.40 & 1.09 & 2.88 & 1.20 \\
\hline $\begin{array}{l}\text { Use of computers/tablets at home for homework } \\
\text { (1: Never/Almost never; 2: Once/Twice a month; 3: Once/Twice a } \\
\text { week; 4: Every day/Almost every day) }\end{array}$ & 2.78 & 1.03 & 2.65 & 1.21 & 3.01 & 1.17 \\
\hline Computers/tablets owned (0:No, 1:Yes) & .22 & .42 & .57 & .50 & .77 & .42 \\
\hline Computers/tablets shared & .91 & .28 & .64 & .48 & .67 & .47 \\
\hline Desk & .88 & .32 & .69 & .46 & .67 & .47 \\
\hline Room & .58 & .49 & .53 & .50 & .68 & .47 \\
\hline Internet connection & .92 & .28 & .58 & .49 & .88 & .33 \\
\hline Mobile phone & .78 & .42 & .23 & .42 & .48 & .50 \\
\hline Gaming system & .53 & .50 & .25 & .43 & .87 & .34 \\
\hline
\end{tabular}

Data were collected from TIMSS 2015 International Results in Science report (Martin et al., 2016a)

towards science in South Korea, Turkey, and the United States (see Table 3 and Table 4) and descriptive statistics of two composite variables (see Table 5) were included in this research to present similarities and differences across three countries.

Results from descriptive statistics of fourth grade students indicated that the number and types of home resources differed in the three countries (see Table 3 and Table 5).

Table 4 Descriptive statistics of fourth graders' attitudes towards science in South Korea, Turkey, and the United States

\begin{tabular}{|c|c|c|c|c|c|c|}
\hline \multirow[t]{2}{*}{ Attitudes Towards Science } & \multicolumn{2}{|c|}{$\begin{array}{l}\text { South Korea } \\
(N=4669)\end{array}$} & \multicolumn{2}{|c|}{$\begin{array}{l}\text { Turkey } \\
(N=6456)\end{array}$} & \multicolumn{2}{|c|}{$\begin{array}{l}\text { United States } \\
(N=10,029)\end{array}$} \\
\hline & $\bar{M}$ & S.D. & $\bar{M}$ & S.D. & $\bar{M}$ & S.D. \\
\hline $\begin{array}{l}\text { I enjoy learning science. } \\
\text { (4: Agree a lot; } 1 \text { : Disagree a lot) }\end{array}$ & 3.28 & .80 & 3.87 & .46 & 3.44 & .88 \\
\hline I learn many interesting things in science. & 3.37 & .76 & 3.78 & .67 & 3.63 & .76 \\
\hline I like science. & 3.20 & .86 & 3.86 & .49 & 3.45 & .90 \\
\hline I look forward to learning science in school. & 2.93 & .95 & 3.62 & .72 & 3.38 & .94 \\
\hline Science teaches me how things in the world work. & 3.27 & .76 & 3.74 & .64 & 3.62 & .75 \\
\hline I like to do science experiments. & 3.64 & .63 & 3.75 & .66 & 3.76 & .66 \\
\hline Science is one of my favorite subjects. & 3.02 & .97 & 3.71 & .67 & 3.24 & 1.02 \\
\hline I usually do well in science. & 2.90 & .77 & 3.76 & .56 & 3.44 & .79 \\
\hline I learn things quickly in science. & 2.83 & .85 & 3.67 & .66 & 3.23 & .93 \\
\hline My teacher tells me I am good at science. & 2.36 & .80 & 3.44 & .80 & 3.05 & 1.02 \\
\hline I wish I did not have to study science. (1: Agree a lot; 4: Disagree a lot) & 3.29 & .87 & 3.61 & 1.12 & 3.32 & 1.45 \\
\hline Science is boring. & 3.32 & .95 & 3.71 & 1.09 & 3.55 & 1.49 \\
\hline Science is harder for me than for many of my classmates. & 3.25 & .84 & 3.32 & 1.28 & 3.29 & 1.40 \\
\hline I am just not good at science. & 2.84 & 1.12 & 3.53 & 1.31 & 3.53 & 1.50 \\
\hline Science is harder for me than any other subject. & 3.29 & .92 & 3.43 & 1.26 & 3.43 & 1.41 \\
\hline Science makes me confused. & 3.23 & .93 & 3.48 & 1.24 & 3.28 & 1.42 \\
\hline
\end{tabular}

Data were collected from the TIMSS 2015 International Results in Science report (Martin et al., 2016a) 
Table 5 Statistics of the composite variables for fourth graders in South Korea, Turkey, and the United States

\begin{tabular}{|c|c|c|c|c|c|c|}
\hline \multirow[t]{2}{*}{ Composite Variables } & \multicolumn{2}{|c|}{$\begin{array}{l}\text { South Korea } \\
(\text { HR } N=4575) \\
(\text { ATS } N=4502)\end{array}$} & \multicolumn{2}{|c|}{$\begin{array}{l}\text { Turkey } \\
(H R N=5254) \\
(\text { ATS N =6085) }\end{array}$} & \multicolumn{2}{|c|}{$\begin{array}{l}\text { United States } \\
(\text { HR N }=9168) \\
\text { (ATS N =9009) }\end{array}$} \\
\hline & M & S.D. & M & S.D. & M & S.D. \\
\hline Home Resources (HR) (2: Minimum; 16: Maximum) & 11.71 & 2.20 & 8.60 & 2.92 & 10.97 & 2.41 \\
\hline Attitudes Towards Science (ATS) (16: Minimum; 64: Maximum) & 49.96 & 9.25 & 58.14 & 7.03 & 53.93 & 9.94 \\
\hline
\end{tabular}

Data were collected from the TIMSS 2015 International Results in Science report (Martin et al., 2016a). 'HR' represents 'Home Resources' and 'ATS' represents 'Attitudes Towards Science'. The N varies between HR and ATS in each country due to differences in the number of participants in each section of the student background questionnaire

South Korean students had a higher number of resources at home $(\mathrm{M}=11.71, \mathrm{SD}=$ $2.20)$, compared to their peers in the United States $(\mathrm{M}=10.97, \mathrm{SD}=2.41)$ and Turkey $(M=8.60, S D=2.92)$. Students in South Korea had more books, and they were more likely to share a computer or tablet at home than students in the United States and Turkey (see Table 3). Additionally, a higher percentage of South Korean students had an Internet connection (92\%), a desk (88\%), and a mobile phone (78\%) at home than United States and Turkish students reported they had. However, more students in the United States had a tablet or computer (77\%), gaming system (87\%), and room (68\%) at home, and frequently used the computer or tablet for their homework $(M=3.01$, $\mathrm{SD}=1.17)$

As opposed to the number of resources at home, Turkish students' attitudes towards science $(M=58.14, S D=7.03)$ were higher than their peers in South Korea $(M=49.96$, $\mathrm{SD}=9.25)$ and the United States $(\mathrm{M}=53.93, \mathrm{SD}=9.94)$ (see Table 5). Results indicated that fourth grade students in Turkey had more positive attitudes towards science. The Turkish students reported they liked science, enjoyed learning in science, and had fewer problems or concerns with science than students in South Korea and the United States stated they had (see Table 4). Based on these findings, an interesting pattern emerged in Turkish students' home resources, attitudes towards science, and achievement in science. Students in Turkey had a higher interest in science and positive attitudes towards science despite having fewer resources at home and lower achievement scores than their peers in South Korea and the United States. Students in South Korea, however, had the highest number of home resources and higher achievement scores in science, but their attitudes towards science were lower than students in Turkey and the United States (see Fig. 1, Table 2, and Table 5).

\section{South Korea}

When looking at the model with two composite variables, attitudes towards science and home resources were found to be significant positive predictors of fourth grade students' science achievement in South Korea $\left(\beta_{K A T S}=.30 ; \beta_{K H R}=.24\right)$. However, $\mathrm{R}$ square seemed to be small $\left(R_{K}^{2}=.16\right)$, indicating that only $16 \%$ variance in fourth grade students' science achievement score was explained by their attitudes towards science and home resources (see Table 6).

Regarding the contributions of specific home resources, the more books owned at home $\left(\beta_{K B}=.37\right)$, the more computer/tablets shared (i.e., less computer and tablet owned individually, $\left(\beta_{K C S}=.14\right)$, and having internet connection $\left(\beta_{K I}=.09\right)$, the more 
Table 6 Multiple regression results with home resources and attitudes towards science as predictors by countries

\begin{tabular}{lllll}
\hline & & $\beta$ Coefficient & Standardized $\beta$ Coefficient & $t$ \\
\hline $\begin{array}{l}\text { South Korea } \\
\text { (HR } N=4575)\end{array}$ & Home Resources (HR) & 6.59 & .24 & $12.13^{* * *}$ \\
$($ ATS $N=4412)$ & Attitudes Towards Science (ATS) & 1.99 & .30 & $16.86^{* * *}$ \\
$\begin{array}{l}\text { Turkey } \\
\text { (HR } N=5254)\end{array}$ & Home Resources (HR) & 7.17 & .23 & $8.61^{* * *}$ \\
$\begin{array}{l}\text { (ATS } N=5936) \\
\text { United States }\end{array}$ & Attitudes Towards Science (ATS) & 5.46 & .41 & $20.04^{* * *}$ \\
$\begin{array}{l}\text { HR } N=9168) \\
\text { (ATS } N=8661)\end{array}$ & Attitudes Towards Science (ATS) & 1.72 & .16 & $11.67^{* * *}$ \\
\hline
\end{tabular}

Data were collected from the TIMSS 2015 International Results in Science report (Martin et al., 2016a). 'HR' represents 'Home Resources' and 'ATS' represents 'Attitudes Towards Science'. The $N$ varies between HR and ATS in each country due to differences in the number of participants in each section of the student background questionnaire. ${ }^{*} p<.05$, ** $p<.01,{ }^{* * *} p<.001$

likely students would have a higher science achievement score in South Korea. Owning a mobile phone negatively predicted science achievement $\left(\beta_{K P}=-.06\right)$, and owning computers/tablets, using a computer/tablet for homework, owning a room, and a gaming system were not significant predictors (see Table 7).

\section{Turkey}

Like South Korea, our results showed that attitudes towards science and home resources significantly predicted fourth grade students' science achievements in Turkey $\left(\beta_{\text {TATS }}=.21 ; \beta_{\text {THR }}=.16\right)$ regardless of a small variance explained by this model $\left(R_{T}^{2}=.20\right)$ (see Table 6). This two-predictor model demonstrated a slightly better fit compared to the model of South Korea.

When examining individual home resources items, we found that the number of books owned at home contributed more than other variables in predicting students' science achievement scores $\left(\beta_{T B}=.22\right)$. The fewer computers/tablets owned individually $\left(\beta_{T C S}=.03\right)$, owning a desk $\left(\beta_{T D}=.06\right)$, a room $\left(\beta_{T R}=.03\right)$, and internet connection $\left(\beta_{T I}=.16\right)$ positively predicted students' science achievement in Turkey. In contrast, using a computer/tablet for homework negatively predicted students' science achievement $\left(\beta_{T C T}=-.08\right)$. Owning a gaming system and phone did not predict students' science scored in Turkey (see Table 7).

\section{United States}

Similar to South Korea and Turkey, attitudes towards science and home resources were found to be significant positive predictors of fourth grade students' science achievement in the United States $\left(\beta_{\text {USATS }}=.21 ; \beta_{\text {USHR }}=.16\right)$. However, $\mathrm{R}$ square was very small $\left(R^{2}{ }_{U S}=.06\right)$, suggesting that this model did not effectively explain variance in the United States students' science achievement (see Table 6).

Regression analysis with individual home resources items demonstrated that owning more books at home $\left(\beta_{U S B}=.26\right)$, a desk $\left(\beta_{U S D}=.06\right)$, a room $\left(\beta_{U S R}=.06\right)$, a gaming system $\left(\beta_{U S G}=.06\right)$, and an internet connection $\left(\beta_{U S I}=.13\right)$ positively contributed to students' science achievement. However, owning more phones $\left(\beta_{U S P}=-14\right)$ and computers/tablets $\left(\beta_{U S C}=-.02\right)$ and using computers/tablets for homework $\left(\beta_{U S C H W}=-.13\right)$ negatively predicted students' science achievement in the United States (see Table 7). 
Table 7 Multiple regression results with home resources items as predictors by countries

\begin{tabular}{|c|c|c|c|c|}
\hline & & $\beta$ Coefficient & Standardized $\beta$ Coefficient & $t$ \\
\hline \multirow[t]{9}{*}{ South Korea $(N=4575)$} & Books & 21.25 & .37 & $19.10^{* * *}$ \\
\hline & $\begin{array}{l}\text { Use of computers/tablets at } \\
\text { home for homework }\end{array}$ & -3.60 & -.06 & $-3.56^{* *}$ \\
\hline & Computers/tablets owned & .08 & .00 & .03 \\
\hline & Computers/tablets shared & 29.58 & .14 & $-7.79^{* * *}$ \\
\hline & Desk & 8.01 & .04 & $2.18^{*}$ \\
\hline & Room & 2.07 & .02 & .80 \\
\hline & Mobile phone & -8.46 & -.06 & $-3.17^{*}$ \\
\hline & Gaming system & 2.22 & .02 & 1.04 \\
\hline & Internet connection & 19.76 & .09 & $4.69^{* * *}$ \\
\hline \multirow[t]{9}{*}{ Turkey $(N=5254)$} & Books & 17.65 & .22 & $10.02^{* * *}$ \\
\hline & $\begin{array}{l}\text { Use of computers/tablets at } \\
\text { home for homework }\end{array}$ & -5.66 & -.08 & $-3.88^{* * *}$ \\
\hline & Computers/tablets owned & 4.69 & .03 & 1.16 \\
\hline & Computers/tablets shared & 27.15 & .15 & $9.59^{* * *}$ \\
\hline & Desk & 11.90 & .06 & $3.16^{* * *}$ \\
\hline & Room & 5.38 & .03 & $1.66^{*}$ \\
\hline & Mobile phone & -.55 & .00 & -.18 \\
\hline & Gaming system & -19.48 & -.09 & -.58 \\
\hline & Internet connection & 28.27 & -.16 & $8.31^{* * *}$ \\
\hline \multirow[t]{9}{*}{ United States $(N=9168)$} & Books & 17.50 & .26 & $20.98^{* * *}$ \\
\hline & $\begin{array}{l}\text { Use of computers/tablets at } \\
\text { home for homework }\end{array}$ & -9.07 & -.13 & $-9.24^{* * *}$ \\
\hline & Computers/tablets owned & -3.82 & -.02 & -1.46 \\
\hline & Computers/tablets shared & 17.65 & .10 & $8.37^{* * *}$ \\
\hline & Desk & 10.39 & .06 & $5.10^{* * *}$ \\
\hline & Room & 10.37 & .06 & $4.67^{* * *}$ \\
\hline & Mobile phone & -22.21 & -.14 & $-12.21^{* * *}$ \\
\hline & Gaming system & 14.44 & .06 & $4.11^{* *}$ \\
\hline & Internet connection & 33.18 & .13 & $9.27^{* * *}$ \\
\hline
\end{tabular}

The number of computers/tablets owned at home did not significantly predict science achievement.

Overall, attitudes towards science and home resources both significantly predicted fourth grade students' science achievement across three countries. However, this model appeared to have limited explanatory power. In terms of specific home resources, the number of books owned at home contributed to fourth grade students' science achievement more than other home resources; this common pattern was observed across three countries. Additionally, having internet connection consistently and negatively predicted students' science achievement in three countries.

\section{Discussion}

In this study, we compared home resources factors and attitudes towards science related to fourth grade students' science achievement in South Korea, Turkey, and the 
United States. South Korean students' science achievement scores were the highest of the three countries, and students in South Korea had the largest number of books in their households, which was a robust influencing factor for science scores across the three countries. The findings could be explained by our theoretical frameworks, which are Social Cognitive Theory (Bandura 1986) and Ecological Systems Theory (Bronfenbrenner 1994). According to these theories, the possible role of environmental factors such as home resources, including students' accessibility to books, is one of the strong factors to predict their learning performance.

Interestingly, Turkish students reported more positive attitudes towards science than South Korean students and the United States students reported that while Turkish science achievement scores were the lowest of the three countries. In the United States, students achieve higher scores and have more resources than Turkish students. Students' attitudes towards science in the United States and South Korea were lower than Turkish students' attitudes, however. According to Bronfenbrenner (1994), individuals' developmental trajectories need to be understood within their personal, interpersonal, social, and cultural contexts. Therefore, we argue that home resources, unique educational systems, and cultural differences among the three countries foster further discussion in relation to the results of this study.

\section{Unique educational systems}

To answer Research Question 1, we found the variabilities in students' attitudes towards science and science performance may be influenced by unique educational systems in the three countries. South Korean students outperformed peers in Turkey and the United States in TIMSS 2015, but their attitudes towards science were very low. This unique pattern may be associated with the country's high standards of academic excellence. Therefore, South Korean students are exposed to the rigorous education system and have too much stress related to high stakes testing resulting in low confidence and motivation in learning science.

Yoon et al. (2014) examined South Korean students' interest and confidence in learning science in third, seventh, and tenth grades. The researchers found South Korean students have difficulties understanding the nature of science and see schools as a place to listen to lectures and do scientific practices in science. The researchers suggested that students' negative attitudes towards science might be related to students' learning experiences in classrooms such as having limited engagement and hands-on activities in science courses (Yoon et al. 2014). Topçu et al. (2016) reported that Turkish students' enjoyment of science had a predictive effect on their science achievement as opposed to South Korean students. Students' level of anxiety, however, affected their achievement scores negatively in both countries.

\section{Cultural differences}

The cultures of South Korea, Turkey, and the United States include varying views about parenting. Parental attitudes may influence children's attitudes towards education at an early age. South Korean parents have higher achievement expectations for their children than European, American, and Latino parents (Okagaki and Frensch 1998; Park and Kim 2006). One possible reason for this feeling may be parents' financial sacrifice 
for their child's education. Their private education, such as cram schools and private tutoring, may increase the financial burden to their parents. Therefore, high parental standards, as well as a strong sense of obligation, could increase the pressure to achieve and affect students' attitudes towards science in general (Okagaki and Frensch 1998; Park and Kim 2006).

Similar to South Korean parents, Turkish parents put attention on students' academic achievement. Sad and Gürbüztürk (2013) provided evidence for Turkish parents' involvement practices in their elementary school aged children's education (such as communicating with children, providing learning environment at home, and helping their homework). Martin et al. (2016a) also reported that $62 \%$ of parents in South Korean parents had positive attitudes towards mathematics and science, whereas $82 \%$ of the Turkish parents seemed to have very positive attitudes. Another study found a positive association between Turkish parents' involvement in education and students' interest in science in elementary school years (Senler and Sungur 2009). On the contrary, Topçu et al. (2016) found no statistical difference between parental involvement and students' science achievement in South Korea and Turkey.

\section{Home resources}

To address Research Question 3, we found that students' home environment plays an important role in their achievement and attitudes towards science (Chen et al. 2012). This finding is aligned with one of this study's theoretical frameworks - the Social Cognitive Theory (Bandura 1986), which states that the environment is a crucial factor that influences one's cognitive development. In line with this theory, "Number of books owned at home", as a salient indicator of the richness of home resources in our study, contributes substantially to students' science achievement. Similar to the results of previous studies (e.g., Juan and Visser 2017; Long 2016), the number of books predicted students' achievement in science across the three countries. Students' ownership of the internet, however, negatively predicted their science achievement, which is consistent with previous research on the use of internet and student learning and achievement (e.g., Ravizza et al. 2014; Zhang and Liu 2016). Moreover, owning a room and desk do not contribute to students' science achievement in Korea, but are weak positive predictors for the United States and Turkey, which is similar to results from a relevant study conducted with TIMSS 2015 mathematics score as outcomes in these three countries (Geesa et al. 2019).

\section{Limitations}

Limitations of this study existed. First, according to Bandura's Social Cognitive Theory, the person-level factor refers to an individual's attitudes, beliefs, and knowledge. Therefore, future studies may include other variables beyond attitudes such as belief and knowledge in predicting science achievement. Second, home resources are considered indicators of students' immediate environment. However, due to the limited variables of the data set, we were not able to include variables at the cultural and societal level, which would represent broader contextual differences. Hence, our results are indicative rather than confirmatory. Third, the book-related items only measured the number of books at home but did not specify the type of books (e.g., subject areas, traditional books or ebooks), which was somewhat vague and lacks explanatory information. Fourth, the home 
resources composite variable demonstrated limited internal consistency; hence, findings associated with the home resource composite variable should be interpreted with causation. Fifth, we only conducted data analysis using fourth graders' student questionnaire similar to previously conducted research (Papanastasiou 2002). It would be worthwhile for future research to examine the effect of students' attitudes and home resources in elementary school years by using multiple questionnaires and longitudinal data.

\section{Conclusions}

We compared home resources and attitudes towards science related to science achievement of fourth grade students in South Korea, Turkey, and the United States. South Korean students have a higher number of books in their homes, and higher science achievement scores than students in Turkey and the United States have from TIMSS 2015. Fourth grade students in the United States have more home resources and achieve higher scores in science than Turkish students earn. Although Turkish students' scores are the lowest among the three counties in TIMSS 2015, their attitudes towards science are higher than attitudes reported by students in South Korea and the United States.

Our TIMSS 2015 data analyses allowed us to further advance our knowledge of relations between attitudes towards science and home resources and achievement in science in South Korea, Turkey, and the United States. Researchers, policymakers, and educators may utilize this data to enhance their understanding of these relations in these three countries for fourth grade students. By capturing students' interest in science and STEM content at an earlier age, a proactive approach can ensure that students are on track through middle and high school to complete the needed coursework for adequate preparation to enter science and STEMrelated degree programs at institutions of higher learning (Dejarnette 2012). In future research, longitudinal studies of science achievement could be pursued if these three countries continue to participate in TIMSS every 4 years.

\section{Implications}

Although science education and the culture of teaching and learning at home and in school vary between countries, analyses of students' attitudes towards science and home resources among South Korea, Turkey, and the United States can further conversations and opportunities for students in those countries, in order to close the achievement gap in STEM disciplines in the future. Results from international standardized tests, such as TIMSS, are useful to educational stakeholders to understand global achievement rankings and trends, evaluate the needs of their education systems, and make required changes in their education systems (Drent et al. 2013; National Center for Education Statistics 2017b). TIMSS provides data to better understand possible reasons for outcomes as well as cross-national comparisons in students' achievement in mathematics and science (McKnight and Schmidt 1998; Ulutan 2018). For example, in Turkey, there is an increase in the number of studies conducted by graduate students and faculty to examine students' and teachers' attitudes towards STEM education after 2012 (Daşdemir et al. 2018; Ulutan 2018). Through evaluating current standings, researching methods to 
improve learning objectives, and implementing changes in teaching and learning approaches for children, individual countries may strengthen their programs and achieve higher scores in science and other STEM disciplines (Creemers 2006).

The emphasis on science education inside and outside of school and the home differ between countries. For example, offering elementary school students science books (such as story books or textbooks) and materials may enhance their intrinsic motivation, and increase their interests towards science courses in the future (Lee and Brophy 1996). In addition, studies from TIMSS data provide researchers opportunities for conducting comparative studies, and learn similarities, differences and trends in science achievement across participating countries (Chiu 2008; Shen and Tam 2008; Wilkins 2004; Yoshino 2012; Yu 2012). Those comparative studies make it possible to offer required changes in science curriculum of countries' education systems. Besides researchers and policy makers, educators and parents may benefit from the findings of our study. By providing students with science books and more resources at home (e.g., private room, Internet access), their science efficacy may increase and contribute to students' interest in science starting from early elementary grades (Juan and Visser 2017).

\section{Abbreviations}

IDB: International Database; IEA: International Association for the Evaluation of Educational Achievement; PISA: Programme from International Student Assessment; STEM: Science, technology, engineering, and mathematics; TIMSS: Trends in International Mathematics and Science Study

\section{Acknowledgements}

Not applicable.

\section{Authors' contributions}

All authors worked on the manuscript throughout the entire process. All authors read and approved the final manuscript.

\section{Authors' information}

Rachel Louise Geesa, Ed.D., is an Assistant Professor of Educational Leadership at Ball State University. Her research agenda includes exploring academic, professional, and personal development and support of educational leaders in national and international settings. Recent studies include topics related to educational leadership and integrative STEM education, mentoring, and school counseling relationships. She taught and served as an administrator in P-12 schools in the United States, South Korea, and Japan.

Burcu Izci, Ph.D., is an Assistant Professor at Florida Gulf Coast University and teaches courses in the Early Childhood Education program. Her research interests include factors that influence home context and parent-child interactions, cross-cultural comparison studies, and children's digital media and technology use. She taught in Turkey and the United States.

Hyuksoon S. Song, Ph.D., teaches pre-service and in-service teachers in Georgian Court University as an Associate Professor of Education. For the last decade, he has participated in medical and science education research. His research interests include integration of emergent technology in K-20 education and self-regulated learning in technologyenhanced learning environments.

Shiyi Chen, Ph.D., is an Assistant Professor at University of Idaho. Her primary research interests include factors that influence early teacher-child relationships and the occupational well being of teachers working with children living in poverty. Shiyi also participates in research projects that focused on early literacy and mathematics education. Exploring the roles of students' home resources and attitudes towards science in science achievement: A Comparison of South Korea, Turkey, and the United States in TIMSS 2015.

\section{Funding}

The authors declare that they have no sources of funding for the research reported.

\section{Availability of data and materials}

The datasets generated and/or analyzed during the current study are available in the following reference: Martin et al. (2016a). TIMSS 2015 International Results in Science. Chestnut Hill, MA: TIMSS \& PIRLS International Study Center, Boston College. Retrieved from: http://timssandpirls.bc.edu/timss2015/international-results/ 
Consent for publication

Not applicable.

\section{Competing interests}

The authors declare that they have no competing interests.

\section{Author details}

${ }^{1}$ Department of Educational Leadership, Teachers College (TC), Ball State University, Room 903, Muncie, IN 47306-0590, USA. ${ }^{2}$ College of Education, Florida Gulf Coast University, Merwin Hall 280, Fort Myers, FL 33965, USA. ${ }^{3}$ School of Education, Georgian Court University, Raymond Hall 206, Lakewood, NJ 08701, USA. ${ }^{4}$ College of Agricultural and Life Sciences, University of Idaho, Margaret School of Family and Consumer Science, 875 Perimeter Drive MS 3183, Moscow, ID 83844-3183, USA.

Received: 29 April 2019 Accepted: 5 November 2019 Published online: 16 December 2019

\section{References}

Agirdag, O. (2018). The impact of school SES composition on science achievement and achievement growth: Mediating role of teachers' teachability culture. Educational Research Evaluation, 24(3-5), 264-276.

Akgündüz, D., Aydeniz, M., Çakmakçı, G., Çavaș, B., Corlu, M. S., Öner, T., \& Özdemir, S. (2015). STEM eăitimi Türkiye raporu: Günün modası mı yoksa gereksinim mi? [A report on STEM Education in Turkey: A provisional agenda or a necessity?] [White Paper]. İstanbul: Aydın Üniversitesi Retrieved from https://www.researchgate.net/publication/281098450_STEM_egitimi_ Turkiye_raporu_G unun_modasi_mi_yoksa_gereksinim_mi_A_report_on_STEM_Education_in_Turkey_A_provisional_ agenda_or_a_necessityWhite_Paper.

Archer, L., Dawson, E., DeWitt, J., Seakins, A., \& Wong, B. (2015). "Science capital": A conceptual, methodological, and empirical argument for extending Bourdieusian notions of capital beyond the arts. Journal of Research in Science Teaching, 52(7), 922-948.

Bandura, A. (1986). Social foundations of thought and action: A social cognitive theory. Englewood Cliffs: Prentice Hall.

Beck, C. W. (2017). Home education: The social motivation. International Electronic Journal of Elementary Education, 3(1), 71-81.

Bronfenbrenner, U. (1994). Ecological models of human development. In International Encyclopedia of Education (Vol. 3, 2nd ed., pp. 1643-1647). Oxford: Elsevier.

Bybee, R. W. (2010a). Advancing STEM education: A 2020 vision. Technology and Engineering Teacher, 70(1), 30-35.

Bybee, R. W. (2010b). What is STEM education? Science, 329(5995), 996. https://doi.org/10.1126/science.1194998.

Carnoy, M., \& Rothstein, R. (2013, January 15). International tests show achievement gaps in all countries, with big gains for U.S. disadvantaged students. Economic Policy Institute Retrieved from http://www.epi.org/blog/international-testsachievement-gaps-gainsamerican-students/.

Chen, S.-F., Lin, C.-Y., Wang, J.-R., Lin, S.-W., \& Kao, H.-L. (2012). A cross-grade comparison to examine the context effect on the relationships among family resources, school climate, learning participation, science attitude, and science achievement based on TIMSS 2003 in Taiwan. International Journal of Science Education, 34(14), 2089-2106. https://doi.org/10.1080/ 09500693.2012.701352.

Cheung, D. (2018). The key factors affecting students' individual interests in school science lessons. International Journal of Science Education, 40(1), 1-23. https://doi.org/10.1080/09500693.2017.1362771.

Chiu, M. (2008). Achievements and self-concepts in a comparison of math and science: Exploring the internal/external frame of reference model across 28 countries. Educational Research and Evaluation, 14(3), 235-254. https://doi.org/10.1080/ 13803610802048858.

Choi, J., \& Cho, R. M. (2016). Evaluating the effects of governmental regulations on south Korean private cram schools. Asia Pacific Journal of Education, 36(4), 599-621. https://doi.org/10.1080/02188791.2015.1064356.

Cohen, J., Cohen, P., West, S. G., \& Aiken, L. S. (2003). Applied multiple regression/correlation analysis for the sciences (3rd ed.). Mahwah: Lawrence Erlbaum Associates.

Council of Chief State School Officers. (2018). Every Student Succeeds Act. Retrieved from https://www.ccsso.org/taxonomy/ term/151

Creemers, B. P. (2006). The importance and perspectives of international studies in educational effectiveness. Educational Research and Evaluation, 12(6), 499-511. https://doi.org/10.1080/13803610600873978.

Daşdemir, l., Cengiz, E., \& Aksoy, G. (2018). Türkiye'de FeTeMM (STEM) Eğitimi Eğilim Araşı̧ıması. Yüzüncü Yıl Üniversitesi Eğitim Fakültesi Dergisi, 15(1), 1161-1183 Retrieved from http://dergipark.org.tr/yyuefd/issue/40566/496235.

Dejarnette, N. K. (2012). America's children: Providing early exposure to STEM (science, technology, engineering and math) initiatives. Education, 133(1), 77-84.

Drent, M., Meelissen, M. R. M., \& Van der Kleij, F. M. (2013). The contribution of TIMSS to the link between school and classroom factors and student achievement. Journal of Curriculum Studies, 45(2), 198-224.

Engler, J. (2012, June 15). STEM education is the key to the U.S.'s economic future. U.S. News \& World Report Retrieved from https:/www.usnews.com/opinion/articles/2012/06/15/stem-education-is-the-key-to theuss-economic-future.

ESSA. (2015). Every student succeeds act of 2015, pub. L. No. 114-95 §114 sat. 1177 (2015-2016). Retrieved from https://www. congress.gov/114/plaws/publ95/PLAW-114publ95.pdf

Fayer, S., Lacey, A., \& Watson, A. (2017). STEM occupation: Past, present, and future (spotlight on statistics). Washington, DC: Department of Labor, Bureau of Labor Statistics Retrieved from https://www.bls.gov/spotlight/2017/science technologyengineering-and-mathematics-stem-occupations-past-present-and-future/pdf/sciencetechnology-engineeringand-mathematics-stem-occupations-past-present-and-future.Pdf.

Geesa, R. L., Izci, B., Song, H. S., \& Chen, S. (2019). Exploring factors of home resources and attitudes towards mathematics in mathematics achievement in South Korea, Turkey, and the United States. EURASIA Journal of Mathematics, Science, \& Technology, 15(9), 1-18. https://doi.org/10.29333/ejmste/108487. 
Gottfried, A. E., Fleming, J. S., \& Gottfried, A. W. (1998). Role of cognitively stimulating home environment in children's academic intrinsic motivation: A longitudinal study. Child Development, 69(5), 1448-1460. https://doi.org/10.1111/j.14678624.1998.tb06223.x.

Gustafsson, J. E., Nilsen, T., \& Hansen, K. Y. (2018). School characteristics moderating the relation between student socioeconomic status and mathematics achievement in grade 8. Evidence from 50 countries in TIMSS 2011. Studies in Educational Evaluation, 57, 16-30.

Halim, L., \& Mokhtar, L. E. (2015). Critical thinking process in science learning. Prosiding Seminar Nasional Pendidikan Sains (SNPS), 2015, 1-4 Retrieved from http://jurnal.fkip.uns.ac.id/index.php/snps/article/view/7900/5749.

IEA. (2013). The IEA International Database Analyzer (IDB Analyzer, Version 3.1) [Computer software]. Hamburg: International Association for the Evaluation of Educational Achievement.

Juan, A., \& Visser, M. (2017). Home and school environmental determinants of science achievement of South African students. South African Journal of Education, 37(1), 1-10. https://doi.org/10.15700/saje.v37n1a1292.

Kaya, S., \& Rice, D. C. (2010). Multilevel effects of student and classroom factors on elementary science achievement in five countries. International Journal of Science Education, 32(10), 1337-1363. https://doi.org/10.1080/09500690903049785.

Kim, J., \& Park, D. (2010). The determinants of demand for private tutoring in South Korea. Asia Pacific Education Review, 11(3), 411-421. https://doi.org/10.1007/s12564-009-9067-3.

Kim, J.-S., \& Bang, H. (2016). Education fever: Korean parents' aspirations for their children's schooling and future career. Pedagogy, Culture \& Society, 25(2), 207-224. https://doi.org/10.1080/14681366.2016.1252419.

Kim, Y. H., Lee, I. H., \& Park, H. J. (1993). A study of Koreans' educational enthusiasm. Seoul: Korean Educational Development Institute. Korean Ministry of Education. (2017). Statistics. Retrieved from: http://english.moe.go.kr/sub/info.do?m=050101 \&page $=050101$ \&num $=1$ \&s=english

Korean Ministry of Education. (2017). Statistics. Retrieved from http://english.moe.go.kr/sub/info.do?m=050101\&page=050101 \&num $=1 \&$ s=english

Kuenzi, J. J. (2008). Science, technology, engineering, and mathematics (STEM) education: Background, federal policy, and legislative action (CRS report no. 35). Retrieved from https://digitalcommons.unl.edu/crsdocs/35/

Lee, H., \& Park, K. (2010). Elementary school students' images of scientists and engineers. Journal of Korean Practical Arts Education, 16(4), 61-82.

Lee, J. K. (2003). Korean higher education: A Confucian perspective. Edison: Jimoondang International.

Lee, J. K. (2006). Educational fever and south Korean higher education. Revista Electronica de Investigacion Educativa (REDIE), 8(1) Retrieved from: http://redie.uabc.mx/vol8no1/contents-lee2.html.

Lee, O., \& Brophy, J. (1996). Motivational patterns observed in sixth-grade science classrooms. Journal of Research in Science Teaching, 33, 303-318.

Long, H. (2016). The suppression role of positive affect on students' science achievement in East Asia: The example of Taipei. Social Psychology of Education, 19(4), 815-842. https://doi.org/10.1007/s11218-016-9358-6.

Malin, J. R., Bragg, D. D., \& Hackmann, D. G. (2017). College and career readiness and the every student succeeds act. Educational Administration Quarterly, 53(5), 809-838. https://doi.org/10.1177/0013161X17714845.

Malley, L., Neidorf, T., Arora, A., \& Kroeger, T. (2016). United States. In I. V. S. Mullis, M. O. Martin, S. Goh, \& K. Cotter (Eds.), TIMSS 2015 encyclopedia: Education policy and curriculum in mathematics and science Retrieved from: http://timssandpirls. bc.edu/timss2015/encyclopedia/.

Mann, A., \& DiPrete, T. A. (2016). The consequences of the national math and science performance environment for gender differences in STEM aspiration. Sociological Science, 3, 568-603.

Martin, M. O., Mullis, I. V. S., Foy, P., \& Hooper, M. (2016a). TIMSS 2015 international results in science. Chestnut Hill: TIMSS \& PIRLS International Study Center, Boston College Retrieved from: http://timssandpirls.bc.edu/timss2015/internationalresults/.

Martin, M. O., Mullis, I. V. S., Foy, P., \& Stanco, G. M. (2012). TIMSS 2011 international results in science. Chestnut Hill: TIMSS \& PIRLS International Study Center, Boston College Retrieved from: https://timssandpirls.bc.edu/timss2011/ internationalresults-science.html.

Martin, S. N., Im, S., \& Song, J. (2016b). Past, present, and future of science, mathematics, engineering, and technology education research and practice in South Korea. Eurasia Journal of Mathematics, Science and Technology Education, 12(7), 1707-1710. https://doi.org/10.12973/eurasia.2016.1529a.

McKnight, C. C., \& Schmidt, W. H. (1998). Facing facts in U.S. science and mathematics education: Where we stand, where we want to go. Journal of Science Education and Technology, 7(1), 57-76. https://doi.org/10.1023/A:1022536200005.

Ministry of National Education. (2018). National education statistics, Formal education 2017/18. Retrieved from http://sgb. meb.gov.tr/meb_iys_dosyalar/2018_09/06123056_meb_istatistikleri_orgun_egi tim_2017_2018.pdf.

Ministry of National Education, General Directorate of Innovation and Educational Technologies (YEĞiTEK). (2016). STEM education report. Retrieved from http://yegitek.meb.gov.tr/STEM_Education_Report.pdf

Ministry of National Education, General Directorate of Innovation and Educational Technologies (YEĞiTEK). (2017). EBA'da düşün, tasarla, kodla... [Think, design, and code on the educational informatics network]. Retrieved from http://yegitek. meb.gov.tr/www/ebadadusun-tasarla-kodla/icerik/1161

Ministry of National Education, General Directorate of Innovation and Educational Technologies (YEĞiTEK). (2018). STEM eğitimi ögretmen el kitabi [STEM education teacher's handbook]. Retrieved from http://scientix.meb.gov.tr/images/ upload/Event_35/Gallery/STEM\%20Eğitimi\%20Öğret men\%20E1\%20Kitabı.pdf.

Ministry of National Education of Turkey. (2017). The curriculum of science lesson (Elementary and Middle Schools, Grades 3, $4,5,6,7,8)$ Retrieved from: http://mufredat.meb.gov.tr/ProgramDetay.aspx?PID $=143$

Mohammadpour, E., Shekarchizadeh, A., \& Kalantarrashidi, S. A. (2015). Multilevel modeling of science achievement in the TIMSS participating countries. The Journal of Educational Research, 108(6), 449-464. https://doi.org/10.1080/ 00220671.2014 .917254$.

Mullis, I. V. S., Martin, M. O., Goh, S., \& Cotter, K. (Eds.) (2016). TIMSS 2015 encyclopedia: Education policy and curriculum in mathematics and science. Retrieved from: http://timssandpirls.bc.edu/timss2015/encyclopedia/

National Center for Education Statistics. (2017a). Back to school statistics. Retrieved from: https://nces.ed.gov/fastfacts/display. asp?id=372 
National Center for Education Statistics. (2017b). Trends in International Mathematics and Science Study (TIMSS): Frequently asked questions. Retrieved from: https://nces.ed.gov/timss/faq.asp

National Science Teaching Association (NSTA) (2018). NSTA position statement: Elementary science education. Retrieved from https://www.nsta.org, https://www.biospace.com/article/releases/national-science-teachers-association-changes-name-tonational-science-teaching-association/

Neuschmidt, O. (2007, September). International Data Base (IDB) analyzer demonstration. Baku. Retrieved from https://www. iaea.info/documents/international-data-base-idb-analyzer-demonstration/.

Next Generation Science Standards. (2013). Next generation science standards: For states, by states. Retrieved from: https:// www.nextgenscience.org/sites/default/files/AllDCl.pdf

Okagaki, L., \& Frensch, P. A. (1998). Parenting and children's school achievement: A multiethnic perspective. American Educational Research Journal, 35(1), 123-144. https://doi.org/10.3102/00028312035001123.

Özdemir, E., Gönen, E., Polat, M.\& \& Akyüz Ari, S. (2016). Turkey. In I. V. S. Mullis, M. O. Martin, S. Goh, \& K. Cotter (Eds.), TMSS 2015 encyclopedia (Turkey): The Science Curriculum in Primany and Lower Secondary Grades Retrieved from: http://timssandpirls.bc. edu/timss2015/encyclopedia/countries/turkey/the sciencecurriculum-in-primary-and-lower-secondary-grades/.

Papanastasiou, C. (2002). School, teaching and family influence on student attitudes toward science: Based on TIMSS data for Cyprus. Studies in Educational Evaluation, 28(1), 71-86. https://doi.org/10.1016/S0191-491X(02)00013-5.

Park, H., Byun, S. Y., Sim, J., Han, H., \& Baek, Y. S. (2016). Teachers' perceptions and practices of STEAM education in South Korea. Eurasia Journal of Mathematics, Science \& Technology Education, 12(7), 1739-1753. https://doi.org/10.12973/eurasia. 2016.1531a.

Park, Y. S., \& Kim, U. (2006). Family, parent-child relationship, and academic achievement in Korea: Indigenous, cultural, and psychological analysis. In U. Kim, K. Yang, \& K. Hwang (Eds.), Indigenous and cultural psychology: Understanding people in context (pp. 421-443). New York: Springer Science + Business Media.

Ravizza, S. M., Hambrick, D. Z., \& Fenn, K. M. (2014). Non-academic internet use in the classroom is negatively related to classroom learning regardless of intellectual ability. Computers \& Education, 78, 109-114. https://doi.org/10.1016/j. compedu.2014.05.007.

Richards, J. C. (2015). The changing face of language learning: Learning beyond the classroom. RELC Journal, 46(1), 5-22.

Sad, S., \& Gürbüztürk, O. (2013). Primary school students' parents' level of involvement into their children's education. Educational Sciences Theory \& Practices, 13(2), 1006-1011 Retrieved from https://files.eric.ed.gov/fulltext/EJ1017261.pdf.

Sang, K., Kwak, Y., Park, S., \& Park, J. H. (2016). Korea, Rep. of. In I. V. S. Mullis, M. O. Martin, S. Goh, \& K. Cotter (Eds.), TIMSS 2015 encyclopedia: Education policy and curriculum in mathematics and science Retrieved from: http://timssandpirls.bc.edu/ timss2015/encyclopedia/.

Schütte, K. (2015). Science self-concept and valuing science: A cross-cultural analysis of their relation among students from Western and east Asian countries. Social Psychology of Education, 18(4), 635-652. https://doi.org/10.1007/s11218-015-9311-0.

Senler, B., \& Sungur, S. (2009). Parental influences on students' self-concept, task value beliefs, and achievement in science. The Spanish Journal of Psychology, 12(1), 106-117. https://doi.org/10.1017/S1138741600001529.

Shen, C., \& Tam, H. P. (2008). The paradoxical relationship between student achievement and self- perception: A crossnational analysis based on three waves of TIMSS data. Educational Research and Evaluation, 14(1), 87-100. https://doi.org/ 10.1080/13803610801896653.

Stables, A., Nöth, W., Olteanu, A., Pesce, S., \& Pikkarainen, E. (2018). Semiotic theory of learning: New perspectives in the philosophy of education. NewYork: Routledge.

TIMSS and PIRLS International Study Center. (2014). The value of participating in TIMSS 2015. Retrieved from https:/ttimss.bc. edu/timss2015/participate.html

Topçu, M. S., Erbilgin, E., \& Arikan, S. (2016). Factors predicting Turkish and Korean students' science and mathematics achievement in TIMSS 2011. Eurasia Journal of Mathematics, Science \& Technology Education, 12(7), 1711-1737. https://doi. org/10.12973/eurasia.2016.1530a.

Tsai, L. T., \& Yang, C. C. (2015). Hierarchical effects of school, classroom, and student-level factors on the science performance of eighth-grade Taiwanese students. International Journal of Science Education, 37(8), 1166-1181. https://doi.org/10.1080/ 09500693.2015.1022625.

Ulutan, E. (2018). Dünyada eğitim trendleri ve ülkemizde STEM öğrenme etkinlikleri: MEB K12 okullari örneği. Retrieved from https://yegitek.meb.gov.tr/meb_iys_dosyalar/2018_11/05144830_Ezgi.pdf

Wellcome Trust. (2011). Exploring young people's views on science education. Retrieved from https://wellcome.ac.uk/sites/ default/files/wtvm052732_0.pdf

Wilkins, J. L. M. (2004). Mathematics and science self-concept: An international investigation. The Journal of Experimental Education, 72(4), 331-346. https://doi.org/10.3200/JEXE.72.4.331-346.

Yoon, S. Y., Suh, J. K., \& Park, S. (2014). Korean students' perceptions of scientific practices and understanding of nature of science. International Journal of Science Education, 36(16), 2666-2693. https://doi.org/10.1080/09500693.2014.928834.

Yoshino, A. (2012). The relationship between self-concept and achievement in TIMSS 2007: A comparison between American and Japanese students. International Review of Education, 58(2), 199-219. https://doi.org/10.1007/s11159-012-9283-7.

Yu, C. H. (2012). Examining the relationships among academic self-concept, instrumental motivation, and TIMSS 2007 science scores: A cross-cultural comparison of five East Asian countries/regions and the United States. Educational Research and Evaluation, 18(8), 713-731. https://doi.org/10.1080/13803611.2012.718511.

Zhang, D., \& Liu, L. (2016). How does ICT use influence students' achievements in math and science over time? Evidence from PISA 2000 to 2012. Eurasia Journal of Mathematics, Science \& Technology Education, 12(9), 2431-2449. https://doi.org/ 10.12973/eurasia.2016.1297a.

Zimmerman, B. J., \& Schunk, D. H. (2003). Albert Bandura: The scholar and his contributions to educational psychology. In B. J. Zimmerman \& D. H. Schunk (Eds.), Educational psychology: A century of contributions (pp. 431-457). Mahwah: Lawrence Erlbaum Associates Publishers.

\section{Publisher's Note}

Springer Nature remains neutral with regard to jurisdictional claims in published maps and institutional affiliations. 